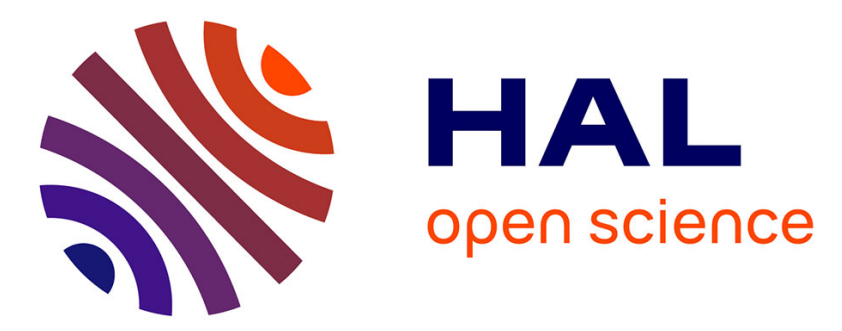

\title{
The mating behavior of Varroa destructor is triggered by a female sex pheromone. Part 2: Identification and dose-dependent effects of components of the Varroa sex pheromone
}

Bettina Ziegelmann, Till Tolasch, Johannes Steidle, Peter Rosenkranz

\section{To cite this version:}

Bettina Ziegelmann, Till Tolasch, Johannes Steidle, Peter Rosenkranz. The mating behavior of Varroa destructor is triggered by a female sex pheromone. Part 2: Identification and dose-dependent effects of components of the Varroa sex pheromone. Apidologie, 2013, 44 (4), pp.481-490. 10.1007/s13592013-0198-5 . hal-01201318

\author{
HAL Id: hal-01201318 \\ https://hal.science/hal-01201318
}

Submitted on 17 Sep 2015

HAL is a multi-disciplinary open access archive for the deposit and dissemination of scientific research documents, whether they are published or not. The documents may come from teaching and research institutions in France or abroad, or from public or private research centers.
L'archive ouverte pluridisciplinaire HAL, est destinée au dépôt et à la diffusion de documents scientifiques de niveau recherche, publiés ou non, émanant des établissements d'enseignement et de recherche français ou étrangers, des laboratoires publics ou privés. 


\title{
The mating behavior of Varroa destructor is triggered by a female sex pheromone. Part 2: Identification and dose-dependent effects of components of the Varroa sex pheromone
}

\author{
Bettina ZiegelmanN ${ }^{1}$, Till Tolasch ${ }^{2}$, Johannes L. M. STEIDLE ${ }^{2}$, \\ Peter Rosenkranz ${ }^{1}$ \\ ${ }^{1}$ Apicultural State Institute, University of Hohenheim, August-von-Hartmann-Strasse 13, 70593 Stuttgart, Germany \\ ${ }^{2}$ Animal Ecology, Institute of Zoology, University of Hohenheim, 70593 Stuttgart, Germany
}

Received 29 May 2012 - Revised 19 December 2012 - Accepted 24 January 2013

\begin{abstract}
Reproduction of female Varroa destructor happens within the sealed brood cell of the honeybee host. The mating represents the last step of the reproductive cycle and is usually performed between the mature male offspring and one or more daughter mites. By offering solvent extracts of freshly molted females to male Varroa mites in our mating bioassay, we could clearly confirm the presence of a volatile female sex pheromone. After separation of the extract into a polar and non-polar fraction, only the polar fraction elicited the typical mating behavior of male mites. GC-MS analysis of the active fraction revealed a pattern of three fatty acids as the main components and the respective ethyl esters. We could prove that all these substances stimulated the male mating behavior, and we present results on the dose-dependent reactions of the males toward these compounds. The identification of a Varroa sex pheromone might enable new options for a biological control of the parasite.
\end{abstract}

Varroa destructor / mating behavior / sex pheromone

\section{INTRODUCTION}

The life cycle of Varroa destructor is closely linked to its honeybee host, without any freeliving stage (Rosenkranz et al. 2010). This is eminently true for the reproduction of the female mites that can only happen within the sealed honeybee brood cells. For the reproductive success of Varroa, it is therefore essential to (1) find a suitable host larva and (2) to complete oogenesis, preimaginal development, and mating of the offspring within the limited time of honeybee brood development. For the close

Corresponding author: B. Ziegelmann,

tinaz@uni-hohenheim.de

Manuscript editor: Yves Le Conte synchronization of the Varroa reproduction with the brood development of the host, chemical cues play an indispensable role. This has already been already confirmed for the host finding behavior that represents the first challenge for mother mites that are ready to start the reproductive cycle. These already inseminated females preferentially parasitize nurse bees (Kraus 1993; Kuenen and Calderone 1997) in order to be transported to unsealed brood cells. It is assumed that these nurse bees are selected by means of an age-dependent hydrocarbon pattern of the bee's cuticle (Chiroudi et al. 1997); Del Piccolo et al. (2010) identified (Z)-8heptadecene as a crucial compound in the selection of the suitable bee stage. The invasion of the suitable brood cell is triggered by the 
kairomonal effect of several fatty acid methyl and ethyl esters of the fifth instar bee larvae (Le Conte et al. 1989, 1994; Troullier et al. 1991, 1992). After entering the brood cell, the start of the mite's oogenesis is immediately activated by yet unknown volatile compounds of the host larva (Milani and Chiesa 1990; Troullier and Milani 1999; Garrido and Rosenkranz, 2004).

It is likely that the mating behavior of $V$. destructor is also triggered by chemical cues. The mating between the mature male offspring and one or more daughter mites represents the last step of the Varroa reproductive cycle and has to be completed within the brood cell before the hatching of the bee. Non-mated daughter mites either seem to die and disappear from the phoretic mite population (Garrido 2004) or should at least be incapable of laying fertilized eggs during the next reproductive cycle. Therefore, daughter mites have to mate immediately after the adult molt when they become sexually mature. That sort of behavior has been described previously (Donzé and Guerin 1994; Donzé et al. 1996) and has been further specified by Ziegelmann et al. (2012) in a laboratory mating bioassay. Ziegelmann et al. (2012) could indeed demonstrate that female mites become attractive to males exactly during the adult molt. In contrast, the female deutochrysalis stage which precedes the adult stage is not attractive to male mites, while the attractiveness of older adult females decreases significantly with age.

So far, the cues triggering the mating behavior within the dark and tight brood cell are unknown. However, we suppose that pheromones released by the young female mite are involved to distinguish females of different ages and to elicit the male's mating behavior. The identification of such a Varroa sex pheromone could possibly be used to disrupt the mating behavior and therefore would be of great importance for the practical beekeeping. The present paper reports on bioassays and chemical analyses of solvent extracts from Varroa females, which have been shown to be most attractive to males in the previous experiments (Ziegelmann et al. 2012).

\section{MATERIALS AND METHODS}

\subsection{Collection of mites}

Male and female Varroa mites were obtained from brood combs of heavily infested Apis mellifera colonies at the Apicultural State Institute, University of Hohenheim in Germany. Sexually mature males and freshly molted adult females as well as female deutochrysalis can be found in brood cells 8 to 9 days after capping. Therefore, brood combs containing pupae of suitable age were taken to the laboratory, and the brood cells were opened with forceps. The required mite stages (female deutochrysalis, freshly molted adult females, adult males; for photographs of these stages see Rosenkranz et al. 2010) were transferred into queen cell cups (Nicot system ${ }^{\circledR}$, Karl Jenter, Metzingen) and kept at $28-30^{\circ} \mathrm{C}$ for maximum $2 \mathrm{~h}$ in order to prevent a decrease in vitality and mobility.

\subsection{Extraction of female $V$. destructor}

Extracts for behavioral assays were prepared in screw-top vials by immersing about 20 young freshly molted female mites, which have been found to be attractive in the bioassay, in diethyl ether (Roth, GC grade $\geq 99.8 \%$, stabilized with $\sim 1 \%$ ethanol) for 2 weeks at $-20{ }^{\circ} \mathrm{C}$. Five microliters of solvent per individual were used. After 2 weeks, the extracts were transferred into new vials and stored at $-20{ }^{\circ} \mathrm{C}$ until use. Diethyl ether was used because other solvents appeared to be unsuitable in preliminary tests (Lindenmayer 2007). For quantitative analyses, we prepared diethyl ether extracts with extraction times of 7 days, $1 \mathrm{~h}$, and $1 \mathrm{~min}$ in the same manner.

\subsection{Fractionation of extracts with column chromatography}

Ether extracts of young attractive females were fractionated on a silica gel micro column. Dry silica gel (0.25 g; Silica gel 60, 0.06-0.2 mm, Roth) was suspended with pentane in a test tube. After pouring the slurry into the column $(7 \mathrm{~cm}$ length, $0.8 \mathrm{~cm}$ I.D., $3.5 \mathrm{~mL}$ ), the silica gel was washed with $10 \mathrm{~mL}$ pentane. The female extracts were evaporated to $5 \mu \mathrm{L}$ and redissolved with $195 \mu$ l pentane. The extract was then pipetted on top of the column and eluted 
sequentially with $2 \mathrm{~mL}$ pentane and $2 \mathrm{~mL}$ diethyl ether. The obtained pentane and diethyl ether fractions were evaporated to a concentration of one female mite equivalent per $5 \mu \mathrm{L}$ and stored at $-20^{\circ} \mathrm{C}$ until use.

\subsection{Mating bioassays}

The responses of male Varroa mites to extracts, fractions, and pure substances were measured by using the "mating bioassay" described in detail in Ziegelmann et al. (2012). For the application of the extracts, the test was slightly modified: total extracts, fractions, and pure substances were applied to a piece of filter paper (size: $1.5 \times 15 \mathrm{~mm}$ ) with a $10-\mu \mathrm{L}$ Hamilton syringe. The filter paper was folded in the middle and placed at the edge of the plastic cell cups (Nicot System ${ }^{\circledR}$, Karl Jenter, Metzingen, 9 mm inner diameter) that served as a test arena. A living female deutochrysalis was placed at the bottom of the cell cup at $3.5 \mathrm{~mm}$ distance to the filter paper. This immobile ontogenetic stage has been proved to be completely non-attractive to the male mite and was therefore used as a dummy. After three tests, the dummies and the cell cups were replaced by new ones. The male responses towards the deutochrysalis were categorized as follows: (1) movement towards/ around the deutochrysalis and palpating it, (2) mounting the dorsum of the deutochrysalis, and (3) copulation attempts on the venter of the deutochrysalis. The duration of each of these behaviors was recorded over a period of 5 min using the Observer 2.0 software (Noldus Information Technology). All tests were performed at temperatures of $28-30{ }^{\circ} \mathrm{C}$ at the bottom of the test arena. This temperature was chosen because the preference temperature of Varroa mites is clearly lower compared to the temperature of the honeybee brood (Le Conte and Arnold 1988; Rosenkranz 1988). Our experience from former laboratory bioassays confirmed an optimal activity of Varroa mites under these temperature conditions.

\subsection{Bioassays with total extracts of young females, fractions of the extracts, and pure substances}

The biological activity of extracts of young females was tested by exposing males to defined amounts of total extract and one living deutochrysalis. The extract was applied to the filter paper in doses of two female equivalents; in control tests, the filter paper was treated with diethyl ether only. Pentane and ether fractions were tested in concentrations of five female equivalents in the same way. The higher concentration was applied in order to equalize possible losses of active substances during the column fractionation. Single substances that were identified from the active fraction (see Section 2.6) were purchased (Sigma Aldrich, GC grade), dissolved in diethyl ether, and were tested in doses of 1, 10, 100, and $1,000 \mathrm{ng}$.

\subsection{Chemical analysis}

Structural analysis of the volatile compounds was performed on a Shimadzu GC-MS combination (GC17A/GCMS-QP 5050A) equipped with a split/splitless injector and a fused silica DB-5 column (30 m× $0.25 \mathrm{~mm}$ I.D., $0.25 \mu \mathrm{m}$ film thickness). The analyses were operated in the splitless injection mode with the following conditions: $60{ }^{\circ} \mathrm{C}$ isothermal for $2 \mathrm{~min}$, followed by a temperature increase at a rate of $4{ }^{\circ} \mathrm{C} /$ min up to $300{ }^{\circ} \mathrm{C}$ that was held for $12 \mathrm{~min}$. The carrier gas was helium at $1.6 \mathrm{~mL} / \mathrm{min}$, and temperatures of the injector and detector were 240 and $280{ }^{\circ} \mathrm{C}$, respectively. For each analysis, $1.5 \mu \mathrm{L}$ of the extract corresponding to five Varroa female equivalents was injected. The compounds of the active fraction were identified by analysis of the mass spectra and retention time followed by co-injection of the identified authentic standards (Sigma).

Quantitative analyses were performed on a Varian GC-MS combination (GC: Varian 3900; detector: Varian Saturn 2100 T MS SIM) equipped with a splitless injector and a fused silica DB-5 column (30 $\mathrm{m} \times 0.25 \mathrm{~mm}$ I.D. and $0.25 \mu \mathrm{m}$ film thickness). The oven temperature was programmed from $50{ }^{\circ} \mathrm{C}$ (isothermal for $3 \mathrm{~min}$ ) to $280{ }^{\circ} \mathrm{C}$ (held for $11 \mathrm{~min}$ ) at a rate of $10{ }^{\circ} \mathrm{C} / \mathrm{min}$. The carrier gas was helium, and the temperatures of the injector and detector were 250 and $280{ }^{\circ} \mathrm{C}$, respectively. For the quantitative analysis of the fatty acids ethyl esters, $1.5 \mu \mathrm{L}$ of the original extract corresponding to five Varroa female equivalents was injected and the peak areas compared with the respective authentic standard analyzed under the same experimental conditions. Free fatty acids in the extracts were derivatized with $\mathrm{N}, \mathrm{O}$ - 
Bis(trimethylsilyl)trifluoroacetamide/BSTFA (Supelco 33148) into trimethylsilyl esters prior to GC analysis.

\subsection{Data analysis}

Behavioral data were analyzed with the SPSS 15.0 statistics software using one-way ANOVA followed by Bonferroni correction. Data sets were checked for normal distribution by Kolmogorov-Smirnov test. In cases of non-normal distribution, a log transformation was performed. If normal distribution could not be achieved, the nonparametric Kruskal-Wallis test was used. The respective tests are given in the results. Differences between groups with $P<0.05$ were considered statistically significant.

\section{RESULTS}

\subsection{Male responses to total extracts of young females and fractions}

Male $V$. destructor did not show any copulatory responses when they were exposed to deutochrysalis and filter paper treated with solvent. Only few single males mounted the female dorsum or moved to the female's venter for a few seconds, but did not show any clear copulation attempts (Figure 1). In contrast,

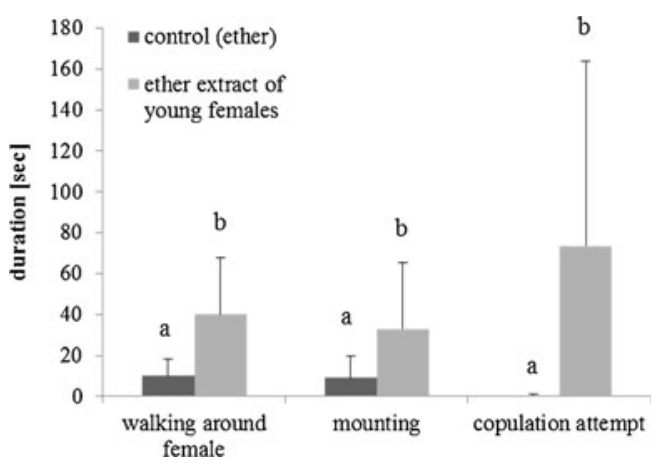

Figure 1. Response of males of $V$. destructor to a female deutochrysalis in the presence of diethyl ether extracts of freshly moulted females applied on filter paper. Pure diethyl ether was used in the control experiments. Extracts were applied in dosages corresponding to two female equivalents. Means with different letters are significantly different (KruskalWallis; $P<0.001 ; n=30$ ). when males were exposed to filter paper containing the total extract of young females, mounting behavior and copulation attempts with the deutochrysalis took place, resembling the typical mating behavior towards young females (Ziegelmann et al. 2012). However, in the venter-to-venter position, males did not pause at the gonopore area on one side but moved from one gonopore to the other. Male responses were highly significant for all three behavioral categories (Kruskal-Wallis, $P<0.001, n=30$ ). Males spent one fifth of the test time with copulation attempts.

In bioassays with fractions of ether extracts of young adult females, the diethyl ether fraction induced significantly more and longer responses of the male for all three behavioral categories than the pentane fraction (Figure 2; walking around female, ANOVA, $P<0.005$, $n=24$; mounting, ANOVA, $P<0.05, n=24$; copulation attempts, ANOVA, $P<0.05, n=24)$. Thereby, the mean duration of copulation attempts of the ether fraction was comparable to responses observed in the presence of the total extract. In contrast, no clear copulation attempts occurred in the presence of the pentane fraction.

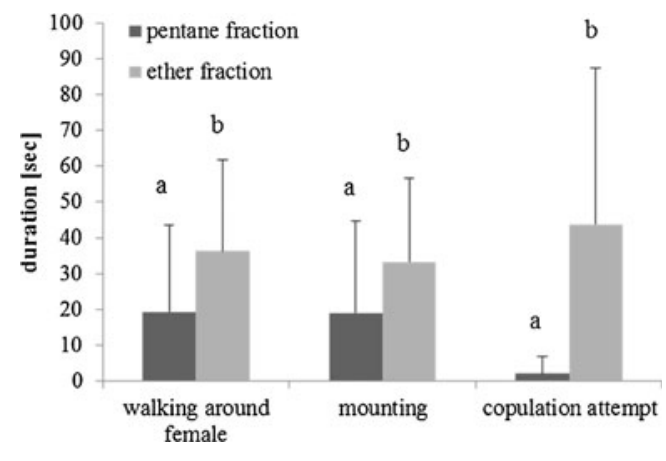

Figure 2. Response of males of $V$. destructor to a female deutochrysalis in the presence of fractions of diethyl ether extracts of freshly moulted females. One female deutochrysalis was offered with filter paper either treated with the pentane fraction $(n=24)$ or the ether fraction $(n=24)$ of the extracts. The used dosages correspond to five female equivalents. Means followed by different letters are significantly different (ANOVA; $P<0.05 ; n=24$ ). 


\subsection{Chemical analysis}

Qualitative GC-MS analysis of the behaviorally inactive pentane fraction revealed a pattern mainly composed of uneven $n$-alkanes with chain lengths of 21-29 carbon atoms and the respective alkenes and methyl alkanes. The biological active polar fraction was dominated by the fatty acids oleic acid, palmitic acid, and stearic acid, as well as their respective ethyl esters (Figure 3). Quantitative analyses revealed that the proportion of the fatty acids and fatty acid ethyl esters differ with the extraction time (Table I). In long-term extracts (1 week), oleic acid was clearly the main component with $61 \mathrm{ng} /$ female and about $50 \%$ of the active substances within the polar fraction. Palmitic acid and stearic acid accounted for $32 \mathrm{ng} /$ female $(26 \%)$ and $25 \mathrm{ng} /$ female (21 \%), respectively, whereas the fatty acid ethyl esters were found in smaller quantities of about $2 \mathrm{ng} /$ female. In the 1-h extract, oleic acid was found in smaller amounts $(17 \mathrm{ng} /$ female corresponding to $33 \%$ ), while the relative amount of palmitic acid $(36 \%)$ and stearic acid $(28 \%)$ increased. In the short-term extract of $1 \mathrm{~min}$, still $5 \mathrm{ng}$ of oleic acid could be found per female mite (20\%), while palmitic and stearic acid were found in higher amounts of $12 \mathrm{ng} / \mathrm{female}(46 \%)$ and $8 \mathrm{ng} /$ female
(33\%), respectively; the ethyl esters were only present in traces.

\subsection{Male responses to pure substances}

In bioassays with synthetic substances identified in the ether fraction, all fatty acids and fatty acid esters were biologically active and elicited the male mating behavior. Copulatory responses to oleic acid were significantly highest at a dosage of $10 \mathrm{ng}$ and lowest at 1,000 ng (Figure 4a, Table II). For ethyl oleate, the same trend was evident (Figure 4b), albeit without significant differences. Palmitic acid, ethyl palmitate, and ethyl stearate also showed maximum copulatory responses at $10 \mathrm{ng}$ and lower responses to other concentrations, but the differences were also not significant (Figure 4c, d, f). In bioassays with stearic acid, the differences between the copulatory responses to the four dosages were low, and the maximal copulation attempts at a dose of $1 \mathrm{ng}$ were lower compared to the other compounds (Figure 4e).

\section{DISCUSSION}

In our previous experiments with freshly moulted young Varroa females, we demonstrated the exceptional attractiveness of this female

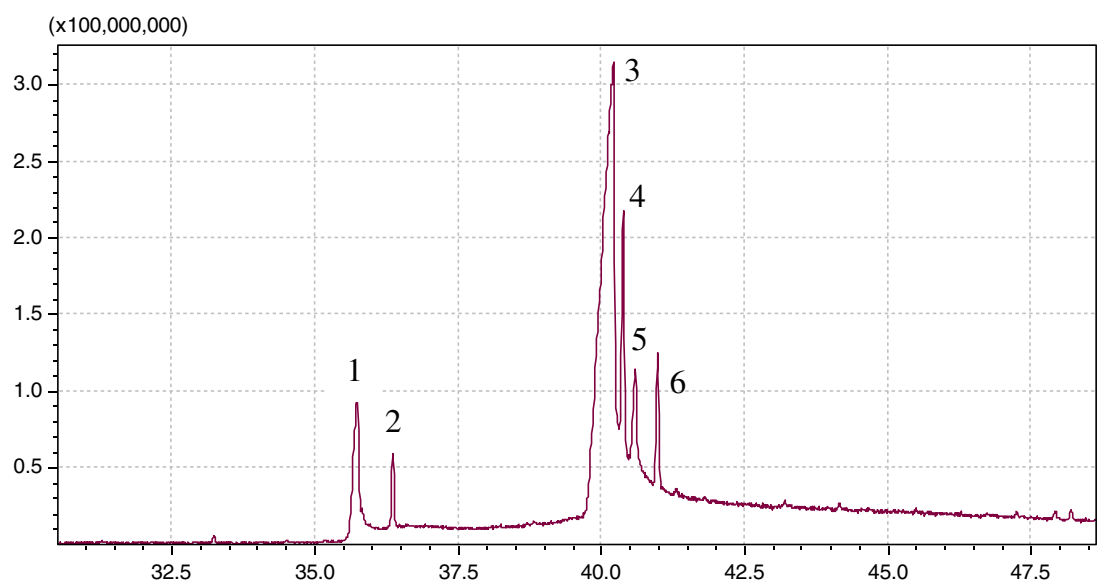

Figure 3. Total ion chromatogram of the diethyl ether fraction of a diethyl ether extract of young females of $V$. destructor. The single substances were identified based on their mass spectra and by co-injection with pure substances. 1 palmitic acid, 2 ethyl palmitate, 3 oleic acid, 4 ethyl oleate, 5 stearic acid, 6 ethyl stearate. 
Table I. Amounts of the biological active free fatty acids and fatty acid ethyl esters in diethyl ether extracts of female $V$. destructor shortly after the adult moult.

Extraction time Concentration (ng/female) (\%)

Palmitic acid Stearic acid Oleic acid Ethyl palmitate Ethyl stearate Ethyl oleate

\begin{tabular}{lllllll}
\hline 7 days & $32.3(26.3)$ & $25.4(20.9)$ & $60.7(50.0)$ & $0.5(0.4)$ & $0.6(0.5)$ & $2.2(1.8)$ \\
$1 \mathrm{~h}$ & $18.9(35.5)$ & $14.8(27.9)$ & $17.3(32.6)$ & $0.8(1.5)$ & $0.6(1.1)$ & $0.7(1.3)$ \\
$1 \mathrm{~min}$ & $11.6(46.3)$ & $8.1(32.6)$ & $5.0(20.1)$ & $<0.2$ & $<0.2$ & $<0.2$ \\
\hline
\end{tabular}

Extraction times varied between $1 \mathrm{~min}$ and 7 days. Values below $0.2 \mathrm{ng} /$ female were not quantified in detail

stage to male mites (Ziegelmann et al. 2012). In the present study, males showed the typical mating cascade and made significant copulation
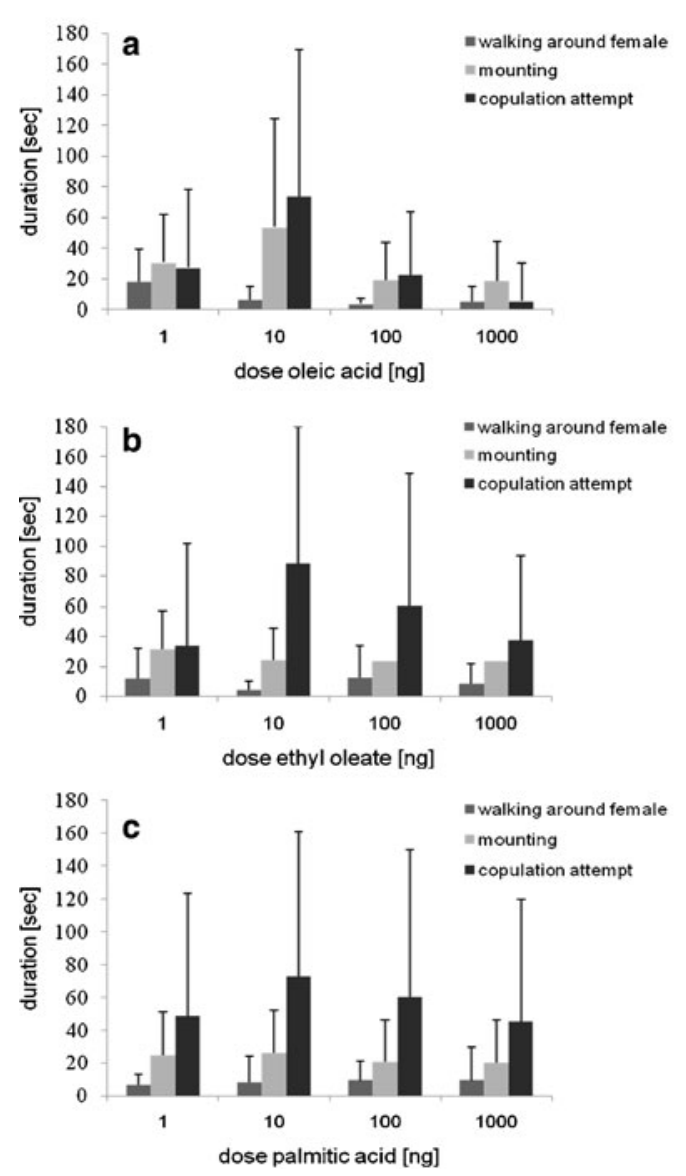

attempts when exposed to diethyl ether extracts of young females together with a deutochrysalis serving as an unattractive dummy. The applica-
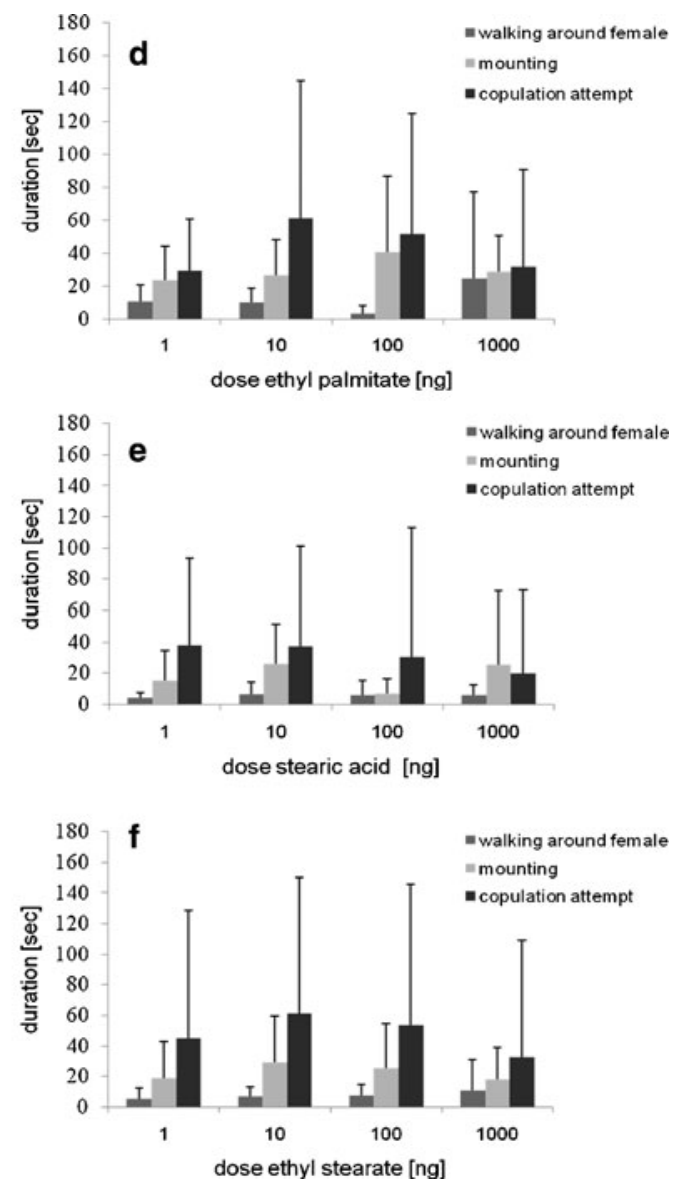

Figure 4. Response of males of $V$. destructor to a female deutochrysalis in the presence of single substances identified in the diethyl ether fraction of extracts of young females. Substances were dissolved in diethyl ether and applied in absolute amounts of 1, 10,100, and 1,000 ng on filter paper. 
Table II. Statistical comparisons of the responses of males of $V$. destructor to a female deutochrysalis in the presence of oleic acid, the main component of the active fraction used in the bioassay (see Figure 3a).

\begin{tabular}{lllllll}
\hline Dose (ng) & $n$ & \multicolumn{5}{l}{ A. Copulation attempt } \\
\cline { 3 - 7 } & & \multicolumn{2}{l}{ Mean (s) \pm SD } & \multicolumn{2}{l}{ Significance } \\
\cline { 3 - 7 } & & & $1 \mathrm{ng}$ & $10 \mathrm{ng}$ & $100 \mathrm{ng}$ & $1,000 \mathrm{ng}$ \\
\hline 1 & 24 & $27.2 \pm 51.0$ & - & 0.182 & 0.785 & $0.002^{* *}$ \\
10 & 24 & $73.8 \pm 95.4$ & - & - & 0.104 & $<0.001^{* * *}$ \\
100 & 24 & $22.6 \pm 40.7$ & - & - & - & $0.004^{* *}$ \\
1,000 & 24 & $5.1 \pm 24.2$ & - & - & - & - \\
\hline
\end{tabular}

Presented are the mean durations of mounting (a) and copulation attempts (b) for applications of 1, 10, 100, and 1,000 ng on filter paper and the corresponding $P$ values

${ }^{* *} P<0.01, * * * P<0.001$, differences between groups were considered statistically significant (Kruskal-Wallis)

tion of the solvent alone did not elicit any specific behavior of the tested males toward the deutochrysalis. Because the male mites made definite copulation attempts with the unattractive and immobile deutochrysalis when extracts of young female mites were offered on filter paper in a distance of several millimeters, the active substances must be volatile. Under the conditions within the tight brood cell, this should enable male mites to perceive attractive young female mites. This confirms that volatile compounds of young adult female mites are the crucial cue stimulating mating behavior of the males, demonstrating for the first time the existence of a female sex pheromone in $V$. destructor.

By use of a simple column chromatography, we separated the extract into one fraction containing six polar compounds and a nonpolar fraction that mainly contained typical cuticular hydrocarbons (Nation et al. 1992). Only the polar fraction elicited the typical male mating behavior ranging from searching, mounting, to copulation attempts indicating that the biological active compounds are only present in this fraction.

The qualitative GC-MS analysis of the polar fraction revealed three fatty acids as main components and their corresponding ethyl esters in clearly lower amounts. In our bioassays, all these substances stimulated the male mating behavior which demonstrates that they are part of the Varroa sex pheromone. These substances are ubiquitous in arthropods and are all derived from the lipid metabolism (Stanley-Samuelson et al. 1988). Their function as semiochemicals is well known, and also, their role as sex pheromones was confirmed for several arthropods. Free fatty acids have been described as part of sex pheromones in some ixodid ticks (Sonenshine 2004), and the here identified fatty acids can be found in the anterior reproductive tract of female ticks of the genus Amblyomma (Allan et al. 1991) and Dermacentor (Allan et al. 1988).

Fatty acids and the respective methyl and ethyl esters have been proved to play a crucial role in the intraspecific communication in honeybees, but are also of utmost importance for the host-parasite relationship between Varroa females and the honeybee larvae. A releaser effect as brood pheromone has been described for a blend of ten fatty acid esters, including ethyl palmitate, ethyl stearate, and ethyl oleate (Le Conte et al. 1990, 2001). The same compounds of the larval cuticle are used by reproductive Varroa females for the host finding (Le Conte et al. 1989; Rickli et al. 1992). Additionally, short-chain fatty acids from the larval food can attract (Nazzi et al. 2004) or repel (Nazzi et al. 2009) Varroa females. After the invasion into a brood cell, also the start of 
the reproduction of the Varroa female is triggered by components of the polar fraction of the larval scent (Troullier and Milani 1999; Garrido and Rosenkranz 2004).

This could indicate that part of the active substances that have been analyzed from extracts of our female Varroa mites derive from the host pupa. However, there are several facts that contradict such an assumption. First, Troullier et al. (1991, 1992) showed that the methyl and ethyl esters on the larval cuticle reach maximal values at the time of cell capping, and the amount of these esters decreases rapidly after capping. In whiteeyed drone pupae, for instance, fatty acid esters are only present in traces. We confirmed this by additional quantitative analysis of extracts of worker pupae 8 days after cell capping. At this developmental stage, only small amounts of fatty acid methyl esters but hardly any ethyl esters are present (Frey et al., personal communication). Second, in an additional control experiment we could demonstrate that the presence of the pupa alone does not elicit the mating behavior (Ziegelmann, unpublished data). Finally, Martin et al. (2002) already confirmed the existence of palmitic acid, stearic acid, and oleic acid in the headspace of adult Varroa females but could not detect oleic acid in methylene chloride extracts of pupae 5 days after capping.

Thus, we can exclude that the identified compounds derive from the bee pupae. The clearly higher amounts of the sex pheromone components in the long-term extract (7 days) compared to the short-term extracts ( $1 \mathrm{~h}, 1 \mathrm{~min})$ indicate that the substances are present within the mite's body and are gradually released to the surface of the cuticle. It can therefore be assumed that the short-term extracts represent a more realistic proportion of the compounds in the headspace compared to longer extraction times. Moreover, a gradual release of the active compounds is also supported by previous experiments showing that the release of the female sex pheromone starts during molt, in the very moment when the exuvia is removed and the gonopores are uncovered. Afterwards, the activity of the pheromone decreases within $24 \mathrm{~h}$ (Ziegelmann et al. 2012). The reason for the extreme decrease might be induced through a stop of pheromone production, through an inhibition of the release through the gonopores, or by the synthesis of an anti-aphrodisiac substance by older females after mating.

The quantification of the substances showed that in all extracts the fatty acids are dominant compared to the ethyl esters. However, at this time we do not know the exact quantity and composition of the pheromone blend emitted by the Varroa females of different ages. The differences in the amounts and the proportions of the compounds according to the extraction time demonstrate that headspace analysis by use of closed-loop stripping apparatus or solidphase microextraction (Schulz et al. 2004) is required to identify the airborne blend of the Varroa sex pheromone.

In our bioassays, all six identified fatty acids and ethyl esters of the polar fraction do elicit the cascade of the male's copulation behavior. The maximum responses toward all compounds were achieved with an application of about $10 \mathrm{ng}$ (Figure 4). At least for the fatty acids, this is within the range of the amount quantified for a single female mite (Table I). The fact that all compounds elicited the mating behavior might indicate a redundancy of the pheromone signal. Under the condition within a closed brood cell and usually brother-sister mating a "fine-tuning" of the pheromonal communication as in different moth species might not be necessary (Wyatt 2003). This, however, must be proved by the application of mixtures with variable numbers and quantities of the six compounds. The exact quantification of the airborne blend within the brood cell and the development of a suitable bioassay to prove possible synergetic, additive, or redundant effects of the single compounds will be a main challenge for further approaches.

For oleic acid, we observed the highest copulatory responses with a maximum duration of copulation attempts at $10 \mathrm{ng}$. However, our results with the pure substances reveal that even high dosages of the pheromone do not deter males from copulation attempts and still have an attracting effect on males. 
The identification of the active compounds of the Varroa sex pheromone enables new options for the control of these mites based on semiochemicals. These could consist in the introduction of the compounds in supernatural concentrations into brood cells to stimulate a repellent effect as in other pheromones (Wyatt 1997). However, our present results do rather support an application of the active pheromone blend to an entire Varroa "family" leading males to believe there are suitable females everywhere. This might confuse males and disrupt an effective mating behavior, in analogy to the mating disruption strategy to control lepidopteran pests (Witzgall et al. 2008). However, it will be a challenge to apply the substances in a suitable way and to prevent side effects in the host. The here published results will hopefully encourage research activities in this direction.

\section{ACKNOWLEDGMENTS}

We thank the Montagu Foundation and the Agroscope Liebefeld-Posieux for providing financial support. Dipl. Eng. Chem. Thomas Blum from the Department of Applied Chemistry of the University of Reutlingen performed the quantitative analysis. We are very grateful for his qualified support.

Le comportement d'accouplement de Varroa destructor est déclenché par une phéromone sexuelle de la femelle. Partie 2: Identification des composants de la phéromone sexuelle de Varroa et leurs effets en fonction de la dose

Acari / Varroa destructor / comportement d'accouplement / pheromone sexuelle / Apidae

Das Paarungsverhalten von Varroa destructor wird durch ein weibliches Sexualpheromon gesteuert. Teil 2: Identifizierung und dosisabhängige Effekte von Komponenten des Varroa Sexualpheromons

Varroa destructor / Paarungsverhalten / Sexualpheromon

\section{REFERENCES}

Allan, S.A., Phillips, J.S., Taylor, D., Sonenshine, D.E. (1988) Genital sex pheromones of ixodid ticks: evidence for the role of fatty acids from the anterior reproductive tract in mating of Dermacentor variabilis and Dermacentor andersoni. J Insect Physiol 34(4), 315-323

Allan, S.A., Phillips, J.S., Sonenshine, D.E. (1991) Role of genital sex pheromones in Amblyomma americanum and A. maculatum (Acari: Ixodidae). Exp Appl Acarol 11, 9-21

Chiroudi, E., Rosenkranz, P., Aumeier, P. (1997) Altersabhängige und rasenspezifische Duftstoffmuster bei Arbeiterinnen der Honigbiene (A. mellifera). Mittlg. der Ges. Allg Angew Entomol 11, 179-182

Del Piccolo, F., Nazzi, F., Della, V.G., Milani, N. (2010) Selection of Apis mellifera workers by the parasitic mite Varroa destructor using host cuticular hydrocarbons. Parasitology 137, 967-973

Donzé, G., Guerin, P.M. (1994) Behavioral attributes and parental care of Varroa mites parasitizing honeybee brood. Behav Ecol Sociobiol 34, 305-319

Donzé, G., Herrmann, M., Bachofen, B., Guerin, P.M. (1996) Effect of mating frequency and brood cell infestation rate on the reproductive success of the honeybee parasite Varroa jacobsoni. Ecol Entomol 21, 17-26

Garrido C. (2004) Reproduktionssteuerung bei der parasitischen Bienenmilbe Varroa destructor Anderson \& Trueman (ehemals Varroa jacobsoni). Ph.D. Thesis at the Faculty of Biology at the University of Hohenheim, $82 \mathrm{pp}$.

Garrido, C., Rosenkranz, P. (2004) Volatiles of the honey bee larva initiate oogenesis in the parasitic mite Varroa destructor. Chemoecology 14, 193-197

Kraus, B. (1993) Preferences of Varroa jacobsoni for honey bees Apis mellifera L. of different ages. J Apic Res 32, 57-64

Kuenen, L.P.S., Calderone, N.W. (1997) Transfers of Varroa mites from newly emerged bee: preferences for age- and function-specific adult bees. J Insect Behav 10, 213-228

Le Conte, Y., Arnold, G. (1988) Etude du thermopreferendum de Varroa jacobsoni Oud. Apidologie 19, 155-164

Le Conte, Y., Arnold, G., Troullier, J., Masson, C., Chappe, B., Ourisson, G. (1989) Attraction of the parasitic mite Varroa to the drone larvae of honeybees by simple aliphatic esters. Science 245, 638-639

Le Conte, Y., Arnold, G., Troullier, J., Masson, C., Chappe, B. (1990) Identification of a brood pheromone in honeybees. Naturwissenschaften 77, 334-336

Le Conte, Y., Streng, L., Troullier, J. (1994) The recognition of larvae by worker honeybees. Naturwissenschaften 81, 462-465

Le Conte, Y., Mohammedi, A., Robinson, G.E. (2001) Primer effects of a brood pheromone on honeybee behavioural development. Proc R Soc London B 268, 163-168

Lindenmayer A. (2007) Chemotaktische Orientierung bei der Partnerfindung und Details des Kopulationsverhaltens der Bienenmilbe Varroa destructor, State 
Examination for Secondary School Teaching Qualification, Dept. of Biology, University of Tübingen.

Martin, C., Provost, E., Bagnères, A.G., Roux, M., Clèment, J.L., Le Conte, Y. (2002) Potential mechanism for detection by Apis mellifera of the parasitic mite Varroa destructor inside sealed brood cells. Physiol Entomol 27, 175-188

Milani, N., Chiesa, F. (1990) Some factors affecting the reproduction of Varroa jacobsoni Oud. under laboratory conditions. Apicoltura 6, 33-42

Nation, J.L., Sanford, M.T., Milne, K. (1992) Cuticular hydrocarbons from Varroa jacobsoni. Exp Appl Acarol 16, 331-344

Nazzi, F., Milani, N., Della, V.G. (2004) A semiochemical from larval food influences the entrance of Varroa destructor into brood cells. Apidologie 35, 403-410

Nazzi, F., Bortolomeazzi, R., Della, V.G., Del Piccolo, F., Annoscia, D., Milani, N. (2009) Octanoic acid confers to royal jelly Varroa-repellent properties. Naturwissenschaften 96, 309-314

Rickli, M., Guerin, P.M., Diehl, P.A. (1992) Palmitic acid released from honeybee worker larvae attracts the parasitic mite Varroa jacobsoni on a servosphere. Naturwissenschaften 79, 320-322

Rosenkranz, P. (1988) Temperaturpräferenz der VarroaMilbe und Stocktemperaturen an Tropenstandorten. Entomol Gen 14, 123-132

Rosenkranz, P., Aumeier, P., Ziegelmann, B. (2010) Biology and control of Varroa destructor. J Invertebr Pathol 103, 96-119

Schulz, S., Fuhlendorff, J., Steidle, J.L.M., Collatz, J., Franz, J.-T. (2004) Identification and biosynthesis of an aggregation pheromone of the storage mite Chortoglyphus arcuatus. ChemBioChem 5, 1500-1507
Sonenshine, D.E. (2004) Pheromones and other semiochemicals of ticks and their use in tick control. Parasitology 129, 405-425

Stanley-Samuelson, D.W., Jurenka, R.A., Cripps, C., Blomquist, G.J., De Renobales, M. (1988) Fatty acids in insects: composition, metabolism, and biological significance. Arch. Insect Biochem. Physiol. 9(1), 1-33

Troullier, J., Arnold, G., Le Conte, Y., Masson, C., Chappe, B. (1991) Temporal pheromonal and kairomonal secretion in the brood of honeybees. Naturwissenschaften 78, 368-370

Troullier, J., Arnold, G., Chappe, B., Le Conte, Y., Masson, C. (1992) Semiochemical basis of infestation of honey bee brood by Varroa jacobsoni. J Chem Ecol 18(11), 2041-2053

Troullier, J., Milani, N. (1999) Stimulation of Varroa jacobsoni Oud. oviposition with semiochemicals from honeybee brood. Apidologie 30, 3-12

Witzgall, P., Stelinski, L., Gut, L., Thomson, D. (2008) Codling moth management and chemical ecology. Annu Rev Entomol 53, 503-522

Wyatt, T.D. (1997) Putting pheromones to work: paths forward for direct control. In: Cardé, R.T., Minks, A.K. (eds.) Pheromone Research: New Directions, pp. 445-459. Chapman \& Hall, New York

Wyatt, T.D. (2003) Pheromones and Animal Behavior: Communication by Smell and Taste. Cambridge University Press, Cambridge

Ziegelmann, B., Lindenmayer, A., Steidle, J., Rosenkranz, P. (2012) The mating behavior of Varroa destructor is triggered by a female sex pheromone, Part 1: Preference behavior of male mites in a laboratory bioassay. Apidologie. doi:10.1007/s13592-012$0182-5$ 